\title{
Presence of Coliform and Fecal Coliform and Evaluation of the Drinking Water Quality in Chittagong University Campus
}

\author{
Sumya Afroze ${ }^{1,2, *}$, Shafayet Ahmed Siddiqui ${ }^{3}$, Belkis Fatama ${ }^{1}$ \\ ${ }^{1}$ Department of Microbiology, University of Chittagong, Chittagong, Bangladesh \\ ${ }^{2}$ School of Life Science, Independent University, Dhaka, Bangladesh \\ ${ }^{3}$ Department of Pharmacy, Atish Dipankar University of Science and Technology, Dhaka, Bangladesh
}

Email address:

sumyasls@iub.edu.bd (S. Afroze)

${ }^{*}$ Corresponding author

\section{To cite this article:}

Sumya Afroze, Shafayet Ahmed Siddiqui, Belkis Fatama. Presence of Coliform and Fecal Coliform and Evaluation of the Drinking Water Quality in Chittagong University Campus. Frontiers in Environmental Microbiology. Vol. 5, No. 1, 2019, pp. 8-13.

doi: $10.11648 /$ j.fem.20190501.12

Received: January 7, 2019; Accepted: February 11, 2019; Published: March 5, 2019

\begin{abstract}
Water contaminated with harmful pathogen and due to the lack of access to safe drinking water can cause various health defects like infection, water born disease and undesirable appearance of water. This study is focused to determine the microbial quality of drinking water in Chittagong University campus which is one of the mostly populated University in Bangladesh. To determine the microbial quality of drinking water, water was collected from three highly populated place of the campus and the sampling sites were canteen of Biological Science Faculty, Deshnetri Begum Khaleda Zia Hall and Canteen near Shahid Minar. For collecting water samples three random place were selected from those collection sites and water samples were collected using standard procedure for three consecutive days. The temperature and $\mathrm{pH}$ was measured at the sampling site; for checking bacteriological parameters (total coliform and fecal coliform) were tested for each sample and their potential for health hazard were measured. Average viable bacterial count in the samples were $13.19 \times 10^{6}, 9.32 \times 10^{6}$ and $9.7 \times 10^{6}$ respectively in sample 1 , sample 2 and sample 3 . The results of the study demonstrated that physicochemical and bacteriological quality of water at sources was not up to the mark. But water from canteen near Shahid Minar (Sample 3) has a very high risk of infection as the number of coliform is $>1100$ and fecal coliform $\cong 93$ and Salmonella was present in that place, demonstrated that water from this site is not safe for drinking. Also Salmonella was found in drinking water sample of canteen of Biological Science Faculty (Sample 1). Possible cause of water contamination may be the irrational practice of drawing water from pipe by suction, improper layout of water supply lines and sewer there might be crossing between them and poor hygienic practice and illiteracy of workers of canteen people. It is recommended that to carryout regular monitoring, crosscheck of the water supply lines.
\end{abstract}

Keywords: Water Quality, Coliform, Fecal Coliform, Cultural Characterization

\section{Introduction}

Safe water for human consumption is outlined by the World Health Organization (WHO) as water that does not cause a substantial hazard to human health while its consumption (World Health Organization, 2004a) [1]. Preservance and development of microorganisms in waters are major threats to human health which is affected by a complex variety of biological, physical and chemical factors
[2]. All Governments should seek to establish regulations to ensure good water quality and therefore to decrease the number of diseases caused by water consumption. Very little attention is being paid to drinking-water quality issues and quantity remains the priority focus of water supply agencies which is unfortunate. There is a lack of drinking-water quality monitoring and surveillance programs in Bangladesh. Lack of well equipped laboratories, weak institutional arrangements, and the absence of a legal framework for 
drinking-water quality issues have aggravated the situation though the government is trying to solve the situation and which is not enough.

The pollution of natural water resources by fecal material, domestic and industrial sewage and agricultural and pasture runoff results in an increased risk of disease transmission to humans who use those contaminated waters [3]. Diarrheal disease from contaminated water continues to be a serious problem in developing countries like Bangladesh and a lesser extent but chronic problem in developed countries [4]. Human pathogenic microorganisms that are very easily transmitted by water include protozoa, bacteria, and viruses. Most of the microorganisms transmitted by water usually grow in the human intestinal tract and reach the outer environment through the feces. Traditionally, the presence of coliform bacteria in drinking water has been seen as an indicator of fecal contamination through cross connection, inadequate treatment, or an inability to maintain a thoroughly disinfectant residual system in the water distribution [5]. Coliform bacteria are regarded as belonging to the genus Escherichia, Citrobacter, Enterobacter, and Klebsiella. Coliform organisms may not always be directly related to the presence of fecal contamination or pathogens in drinking water although the coliform test is still practicable for supervising microbial quality of water supplies [6].

Bangladesh is a country with about 130 million people living in an area of 148,393 square kilometer making the country one with the highest population density in the world. Economically Bangladesh is in a less than an enviable position; it is generally ranked among the world's 10 poorest countries. In this agrarian country over $80 \%$ of the population of Bangladesh live in the 64,000 villages. Other gastro-intestinal diseases like diarrhea are caused by pathogens that are water-borne either are carried through the medium of water. These diseases account for nearly a quarter of all illnesses in Bangladesh -nearly $12 \%$ by diarrhea, and $10 \%$ by other gastro-intestinal illness including enteric fever. So drinking water plays a key role for the overall disease profile of the country [7].

The University of Chittagong is one of the largest University of Bangladesh with total students of approximately 25,000 with little opportunity to live in University Hall and most of them manage to live outside, is one of the major reasons to have potential health risk by drinking contaminated water from outside. Our main objective is: (1) to evaluate the quality of drinking water outside University Hall and (2) to suggest preventive measures for the improvement of the quality of drinking water in the campus area.

\section{Materials and Methods}

\subsection{Sampling Area}

Drinking water samples were collected from three important place of University of Chittagong (CU): canteen of Biological Science Faculty, Deshnetri Begum Khaleda Zia Hall and Canteen near Shahid Minar were immediately subjected to physicochemical and bacteriological analysis. We analyzed the microbiological quality of the drinking water of the three most populated place of Chittagong University campus in the microbiology lab at the Department of Microbiology, CU. Collected water were immediately transferred to lab and preserved at $4^{\circ} \mathrm{C}$. The microbiologic data refers to the time period of July 2018 where 3 samples from each spots were collected meticulously in the sterile container.

\subsection{Parameters Tested}

Four water quality parameters; two physical, two bacteriological were tested for the samples collected for this research work. Physical parameters testes were $\mathrm{pH}$ and temperature. These two parameters play an important role in the disinfection of water. The $\mathrm{pH}$ of water should be less than 8 for effective disinfection. Bacteriological quality of drinking water was determined by presumptive coliform test followed by confirmation test. These parameters indicate the possibility of the presence of pathogenic bacteria in the supplied water. Total viable bacterial count (TVBC), total count of coliform, fecal coliform; and isolation and identification of Citrobacter, Salmonella were done. A complete detail and nomenclature used for the sampling locations used is given in Table 1 .

\subsection{Sampling Site and Collection}

Drinking water samples were collected from three different places of University of Chittagong. The place of drinking water collection are presented in the following Table 1.

Table 1. The Place of collection of water sample.

\begin{tabular}{lll}
\hline Sample No. & Sample type & Place of Collection \\
\hline 1 & Drinking water & Canteen of Biological Science Faculty, CU campus \\
2 & Drinking water & Canteen of Deshnetri Khaleda Zia Hall, CU campus \\
3 & Drinking water & Canteen near Shahid Minar Canteen (Jhupri), CU campus \\
\hline
\end{tabular}

Samples were collected aseptically from sample collection sites in sterile container, brought to the laboratory and preserved at $4^{\circ} \mathrm{C}$. The color, $\mathrm{pH}$ and date of collected samples were recorded and presented in Table 2. The $\mathrm{pH}$ of the samples were determined by $\mathrm{pH}$ meter $(\mathrm{pH}$ Hanna Instrument Ltd. \& 3310, pH meter Jenway, UK.). 
Table 2. The date, time, color and $p H$ of the collected samples.

\begin{tabular}{lllll}
\hline No. of sample & Date of collection & Time of collection & Color of sample & pH Temp. $\left({ }^{\circ} \mathbf{C}\right)$ \\
\hline 1. & 5 to 7 July 2018 & $10.00 \mathrm{am}$ & Yellowish & 727.8 \\
2. & 5 to 7 July 2018 & $11.00 \mathrm{am}$ & Transparent & 7.228 .1 \\
3. & 5 to 7 July 2018 & $01.00 \mathrm{pm}$ & Transparent & 6.9527 .9 \\
\hline
\end{tabular}

\subsection{Enumeration of Total Viable Bacteria}

Serial dilution plate procedure was done by following the method of Foster et al., [8] was used for the isolation of microbial colonies. For this purpose, $1 \mathrm{ml}$ of sample was taken in $9 \mathrm{ml}$ of the sterile distilled water in a sterile comical flask and shaken by a vortex stirrer or by hand. It was used as the $10^{-1}$ dilution. $1 \mathrm{ml}$ of this suspension was transferred to 9 $\mathrm{ml}$ of sterile distilled water for tenfold (1:9) dilution and further diluted up to $10^{-7}$ dilution in sterile distilled water. For standard plate count $1 \mathrm{ml}$ of each dilution was plated on sterile Petri plates by sterile pipette. Approximately $15 \mathrm{ml}$ of sterilized melted and cooled $\left(45^{\circ} \mathrm{C}\right)$ plate count agar (PCA) was poured into the plates. The plates were rotated clockwise and anticlockwise for equal distribution of the media. Then the plates were allowed to solidify. After solidification of the media, the plates were incubated at $37^{\circ} \mathrm{C}$ for $24-72$ hours in an incubator at inverted position. Plates, which contained 30300 bacterial colonies, were selected and counted. The arithmetic average of the two counts for every dilution were taken and multiplied by the respective dilution factor to get the result. This method was completely enumerated by Collins and Lyne et al., [9]. The calculated result expressed as colony forming unit (cfu) per $\mathrm{ml}$ of water.

\subsection{Enumeration of Total Coliform and Fecal Coliform}

Enumeration of coliforms was done by MPN (Most Probable Number) method (Oblinger and koburger). Serial dilutions of the samples were prepared as described in section 4. a. [1]. 10 test tubes containing MacConkey broth were taken and an inverted Durham's tube was added to each test-tube in such a way that there was no air bubble. After sterilization, 3 test tubes were inoculated with $1 \mathrm{ml}$ from $10^{-1}$ dilution, 3 test tubes were inoculated with $1 \mathrm{ml}$ from $10^{-2}$ dilution, another 3 test tubes were inoculated with $1 \mathrm{ml}$ from $10^{-3}$ dilution and one test tube without sample was maintained. The test tubes were kept in incubator at $35^{\circ} \mathrm{C}$ for 48 hours. Gas and acid production in Durham's tubes indicated positive result. Test tubes showing positive result (gas production in Durham's tube) were counted and recorded.. Results were computed using MPN chart as total coliform number per ml.

\subsection{Isolation and Purification of Indicator Organism}

For this purpose, drinking water samples were inoculated into Nutrient broth for enrichment for $24 \mathrm{hrs}$. at $35^{\circ} \mathrm{C}$ and after incubation one loopful culture was streaked on selective media BSA and MacConkey Agar for isolation of Salmonella and Citrobacter, respectively. The resulted colonies were streaked repeatedly for purifying single type of colony. Isolates were then maintained on the Nutrient agar slants during the course of investigation.

\subsection{Coding of the Isolates}

The pure cultures of the isolates were coded according to the medium used and the serial of the sample used. The code numbers of the sample were maintained and followed till identification of the isolates after through characterization. Isolates from BSA agar were coded with $\mathrm{BB}_{\mathrm{S}}, \mathrm{JB}_{\mathrm{S}}$ and isolate from MacConkey was coded with JE shown in Table 3.

\subsection{Morphological and Cultural Studies of Selected Isolates}

Identification of the microorganisms was a sequential process, which included a series of different types of experiments. The bacterial colonies grown on plating agar media (BSA agar and MacConkey agar) were studied for their morphological characteristics such as size, shape, edge, elevation, opacity, color. For observation of the above characteristics the inoculation temperature and period were kept constant (i.e. $37 \pm 1^{\circ} \mathrm{C}$ for $24-48$ hours). The isolates were then transferred to BSA agar and MacConkey slants. The modes of bacterial growth on slants such as rhizoidal, spreading, adhering or slimy. In case of microscopic study the size and shape of the vegetative cells were determined. The arrangement of cells whether present singly, in chain or in cluster were also observed. The selected isolates were inoculated in nutrient broth medium. The characteristics of growth in broth was observed visually and noted. Production of turbidity and distribution of growth in broth was observed and recorded. For microscopic light examination of the isolates, methods of Balkwill et. al [10] were used for this purpose to make a fixed stained smear. And for the staining of the isolates gram staining [11], acid-fast staining [12], spore staining [13] were done by following the respective methods.

\subsection{Biochemical Studies of the Selected Isolates}

Some bacteria are motile because of the presence of flagella. To observe the presence or absence of flagella, motility test was done. Motility test was done by following the method of Eklund and Lankford [14]. Citrate utilization can be used to distinguish between coliforms such as Enterobacter and fecal coliforms such as Escherichia coli whose presence would be indicative of fecal contamination and it is done by following standard procedure. TSI slant media is also used for the confirmation of presence of bacteria. Indole is produced by the action of bacteria by tryptophanase acting on amino acid tryptophan. Presence of pink or deep cherry color in indole test confirms the presence of enteric bacteria. Voges-proskauer test was done by 
following the method of MacFaddin et. al.,[15, 16]. In case of methyl-red test method described in Bryan [16] was followed and a distinct red color of the broth indicates positive result whereas yellow or yellowish-red color indicates negative result. Fermentation test has considerable significance in the identification and classification of bacteria and actinomycetes. The microorganisms differ in their ability to ferment different carbohydrates which is done by following the procedure [17] described. Urease test described by Eklund and Lankford [14] can be used for the identification of several genera and species of Entero bacteriaceae, including Proteus, Klebsiella and some Yersinia and Citrobacter species as well as some Corynebacterium species.

\section{Result and Discussion}

\subsection{Temperature, $\mathrm{pH}$ and Bacterial Count}

The temperature, $\mathrm{pH}$ and the numbering of sample were detailed and they were discussed in Table 1 and Table 2. Total viable count of sample 1, 2, 3 were on average $13.19 \times 10^{6}, 9.32 \times 10^{6}$ and $9.7 \times 10^{6}$ respectively which is described in the following figure (Figure 1). As there is no health guidelines are proposed by WHO for the $\mathrm{pH}$ of drinking water. However, it is one of the most important operational water quality parameters. The $\mathrm{pH}$ higher than 8 are not suitable for effective disinfection while values less than 6.5 enhance corrosion. There is a high number of bacterial count in the drinking water which indicates us the possible presence of coliform and fecal coliform or any other harmful bacteria in the drinking water samples. The temperature and $\mathrm{pH}$ in Table 1 and Table 2 shows that it was in favor for bacterial growth also the bacterial count data support it.

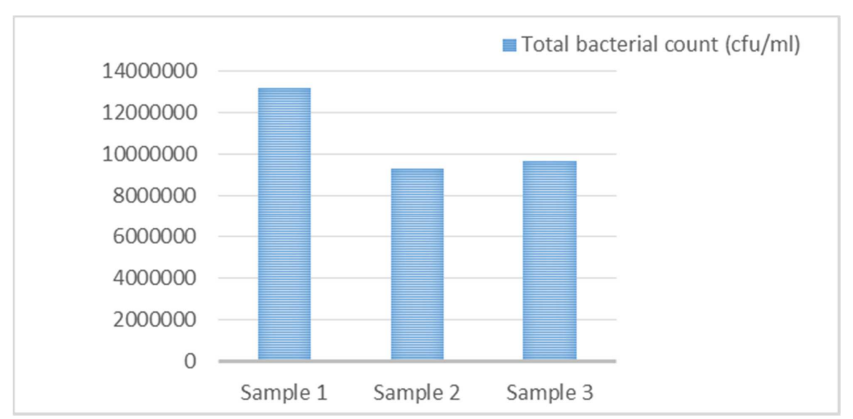

Figure 1. Total bacterial count (cfu/ml).

\subsection{Cultural Characterization}

For cultural characterization each samples were inoculated in BSA and MacConkey media and they were named as BBs, $\mathrm{JBs}$ and JEs. Isolates BBs and JBs on BSA media and isolates JE on MacConkey agar showed different types of colonies. The cultural characteristics of different isolates on selective media are shown in the following Table 3

Table 3. List of isolates, their cultural and slant characteristics in different media.

\begin{tabular}{llllll}
\hline \multirow{2}{*}{ Isolates } & Cultural characters & & & & \\
\cline { 2 - 5 } & Media & Color & Elevation & Margin & Form \\
\hline $\mathrm{BB}_{\mathrm{S}}$ & $\mathrm{BSA}$ & Black & Pulvinate & Entire & Punctiform \\
$\mathrm{JB}_{\mathrm{S}}$ & $\mathrm{BSA}$ & Black & Pulvinate & Entire & Echinulate \\
$\mathrm{JE}_{\mathrm{S}}$ & MacConkey & Dark pink & Convex & Entire & Punctiform \\
\hline
\end{tabular}

\subsection{Morphological Characters}

Selected isolates were observed under microscope. Size and arrangement of vegetative cells, Gram reaction, acid fast reaction and spore staining were observed under microscope after proper staining of the isolated bacteria. Isolates were found to be Gram negative, non-acid fast and non-spore former. Short rod form were observed in case of vegetative cells. The morphological characters of different isolates were shown in Table 4.

Table 4. Morphological Characters of different isolates.

\begin{tabular}{lllll}
\hline Isolates & Form & Arrangement & Gram Staining & Endospore Staining \\
\hline $\mathrm{BB}_{\mathrm{S}}$ & Short rod & Single and in pair & Negative & Non-spore former \\
$\mathrm{JB}_{\mathrm{S}}$ & Short rod & Single and in pair & Negative & Non-spore former \\
$\mathrm{JE}$ & Short rod & Single and in pair & Negative & Non-spore former \\
\hline
\end{tabular}

\subsection{Characterization and Identification of Selected Isolates}

Three isolates were finally selected from three groups for detail study. Purpose of characterization and identification is to place the microorganisms into a specific class or group so that the characteristics of these unknown organisms can be compared with standard description. The bacterial isolates were characterized on the basis of their morphological characteristics including size and shape of the organism, arrangement of the cells, presence or absence of the spores, regular or irregular forms, acid fastness, gram reaction etc.; cultural and $\mathrm{IMViC}$ test, $\mathrm{H}_{2} \mathrm{~S}$ production, fermentation of different carbohydrates etc. 

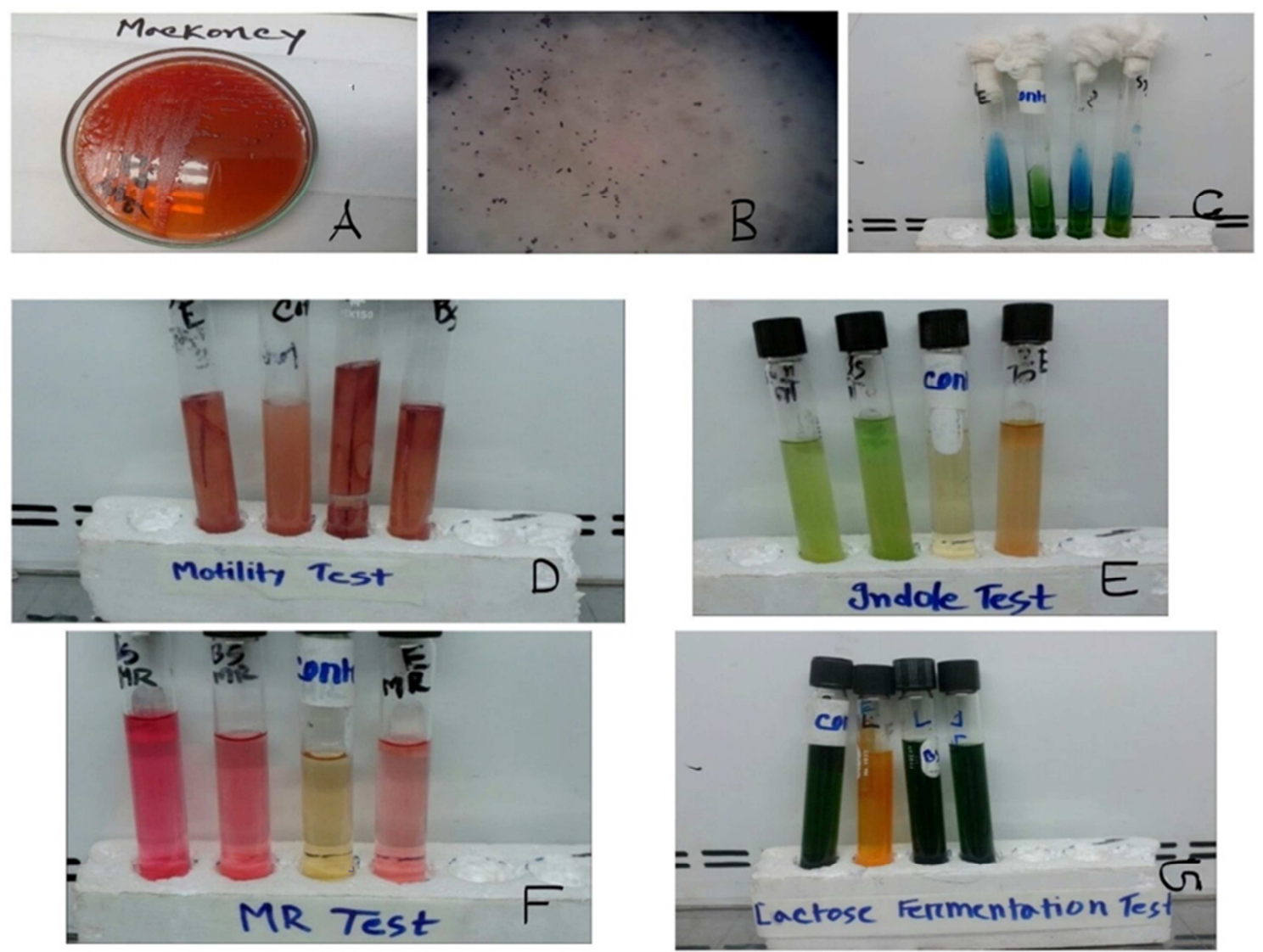

Figure 2. Characterization and identification of the isolates; A) Isolates grown in Mac Conkey agar media B) Vegetative cell view of the isolates under microscope C) Citrate utilization test of the selected isolates D) Motility test of the isolates E) Image of Indole test F) Methyl Red test of selected isolates G) Lactose Fermentation test of isolates.

Table 5. Cultural, Physiological and Biochemical Characteristics of the bacterial isolate BBS, JBs and JE.

\begin{tabular}{|c|c|c|c|}
\hline \multirow{2}{*}{ Parameters } & $\mathrm{JE}$ isolates & JB Isolates & BB Isolates \\
\hline & Observations & Observations & Observations \\
\hline \multirow{4}{*}{ Agar colony } & Form- Punctiform & Form- Punctiform & Form- Punctiform \\
\hline & Elevation- Convex & Elevation- Pulvinate & Elevation- Pulvinate \\
\hline & Margin- Entire & Margin- Entire & Margin- Entire \\
\hline & Color- Dark Pink & Color- Black & Color- Black \\
\hline Slant character & Filiform & Echinulate & Echinulate \\
\hline Microscopic observation & Short rod, single \& in pair & Short rod, single \& in pair & Short rod, single $\&$ in pair \\
\hline Gram staining & Gram negative & Gram negative & Gram negative \\
\hline Spore staining & Non spore former & Non spore former & Non spore former \\
\hline Acid fast staining & Non acid fast & Non acid fast & Non acid fast \\
\hline Motility test & Motile & Motile & Motile \\
\hline Indole test & Positive & Negative & Negative \\
\hline Methyl Red (M. R.) test & Positive & Positive & Positive \\
\hline TSI Slant & Not done & Positive & Positive \\
\hline Voges-Proskakauer & Negative & Negative & Not done \\
\hline Citrate utilization & Positive & Positive & Negative \\
\hline Urease test & Not done & Negative & Negative \\
\hline Fermentation test & $\begin{array}{l}\text { Acid and gas from glucose, mannitol } \\
\text { without lactose }\end{array}$ & $\begin{array}{l}\text { Acid and gas from glucose, mannitol } \\
\text { without lactose }\end{array}$ & $\begin{array}{l}\text { Acid and gas from glucose, mannitol } \\
\text { without lactose }\end{array}$ \\
\hline
\end{tabular}

From the above data it can be concluded that isolate JE belongs to the genus Citrobacter and found closely related to the species Citrobacterfreundii while isolate $\mathrm{BB}_{\mathrm{S}}$ and JBsbelongs to the genus Salmonellae and found closely related to the species Salmonella bongori with the standard description given in and compared with the standard description given in Bergey's 'Manual of Determinative
Bacteriology' [18].

\subsection{Enumeration of Coliform and Fecal Coliform}

Coliform and fecal coliform was not present in Sample 1 and Sample 2 but was present in Sample 3. The list is given below in Table 5. The result shows that there are presence of 
coliform and fecal coliform in the canteen near Shahid Minar but the other sample do not have any coliform and fecal coliform which indicates the other sample sites do not have the risk of coliform and fecal coliform infection.

Table 6. List of the presence of coliform and fecal coliform in the samples.

\begin{tabular}{lll}
\hline No. of sample & Total coliform count per 100ml & Total fecal coliform count per 100ml \\
\hline 1 & 0 & 0 \\
2 & 0 & 0 \\
3 & $>1100$ & 93 \\
\hline
\end{tabular}

From the study we can conclude that, the temperature of drinking water sample was $29^{\circ} \mathrm{C}$ and the $\mathrm{pH}$ (6.5-8.5) of the water was within standard according WHO guidelines [1] which favors the growth of microorganisms. Total viable bacterial count of all three drinking water samples from different sources were higher than guideline's values. Elevated microbial count in water is undesirable because of the increased bacteria likelihood that pathogens may be present, the possibility that these organisms will find access to foods and drink thereby causing spoilage. coliform and fecal coliform was not present in the drinking water collected from the canteen of Biological Science Faculty and Deshnetri Khaleda Zia Hall but present in canteen near Shahid Minar. Citrobacter (JE) was found in the drinking water of canteen near Shahid Minar and Salmonella $\left(\mathrm{BB}_{\mathrm{S}}\right.$ and $\mathrm{JB}_{\mathrm{S}}$ ) was present in the drinking water of canteen of Biological Science Faculty and canteen near Shahid Minar. This study revealed that, the water of canteen near Shahid Minar was more polluted than the other two water sources while the other two sources has got potential risk to grow infection due to the presence of Salmonella.

All three sampling sites were supplied with water from underground water pump at University of Chittagong, so higher water pollution in canteen near Shahid Minar may involve number of factors, like: illogical practice of drawing water from pipe by suction, improper layout of water supply lines and sewer there might be crossing between them, poor hygienic practice and illiteracy of workers of canteen people etc. It is suggested that water quality should be monitored regularly and drinking water should be treated or boiled to reduce the risk of contamination before consumption in these places.

\section{Conclusion}

From the discussion above we can now confirm that our sample sites have got a potential risk to grow pathogenic infection. It can be concluded that there was no relation between the enteric pathogen with the presence of fecal coliform.

\section{References}

[1] World Health Organization, Guidelines for Drinking Water Quality, 3rd ed., 2004

http://www.who.int/water_sanitation_health/dwq/gdwq3rev/en.

[2] K. L. Anderson, J. E. Whitlock, V. J. Harwood, "Persistence and Differential Survival of Fecal Indicator Bacteria in Subtropical
Waters and Sediments" Appl. Environ. Microbiol., vol. 71, no. 6, pp. 3041-3048, 2005.

[3] E. E. Geldreich, "Microbial water quality concerns for water supply use.” Environ. Toxicol. Water Qual., vol. 6, no. 2, pp. 209223, 1991.

[4] M. A. Grant, "A New Membrane Filtration Medium for Simultaneous Detection and Enumeration of Escherichia coli and Total Coliforms," Appl. Environ. Microbiol., vol. 63, no. 9, pp. 3526-3530, 1997.

[5] M. W. LeChevallier, N. J. Welch, and D. B. Smith., (1996) "Fullscale studies of factors related to coliform regrowth in drinking water," Appl. Environ. Microbiol., vol. 62, no. 7, pp. 2201-2211.

[6] dWHO. 1993. Guidelines for Drinking-Water Quality, Volume 1, 2nd edition, Geneva: Recommendations.

[7] jWater Borne Disease. (2018, gDecember, 16). Retrieved from $\mathrm{http}: / /$ en.banglapedia.org/index.php?title=Water-borne Disease.

[8] E. H. Marth, J. Steele, Applied Dairy Microbiology (Food Science and Technology), Marcel Dekker, 1998.

[9] C. H. Collins, P. M. Lyne, J. M. Grange, J. O. Falkinham III, $8^{\text {th }}$ ed., Arnold, 2004.

[10] D. L. Balkwill and W. C. Ghiorse, "Characterization of Subsurface Bacteria Associated with Two Shallow Aquifers in Oklahoma," Appl. Environ. Microbiol., vol. 50, no. 3, pp. 580588, 1985.

[11] J. W. Bartholomew, and T. Mittwer, "The Gram Stain," Bacteriol. Rev., vol. 16, no. 1, pp. 1-29, 1952.

[12] Cowan and Steel (1985) Manual for the Identification of Bacteria. Cambridge University Press, Cambridge.

[13] Schaeffer, A. B. and MacDonald, F. (1933) A simplified method of staining endospores. Science 77, pp194.

[14] Eklund C. and Lankford C. E. (1967). Laboratory manual for general microbiology Prentice-Hall International, Inc., London. pp299.

[15] MacFaddin, J. F. (1980). Biochemical Tests for Identification of Medical Bacteria, 2nd ed. Williams and Wilkins, Baltimore.

[16] Bryan, H. (1950). Manual of methods for pure culture study of bacteria. McGraw Hill BookCo. lnc, Newyork, pp12.

[17] SAB (Society of American Bacteriologists) (1957). Manual of Microbiological Methods. McGraw-Hill Book Co. Inc. NewYork, London. pp315.

[18] Buchanan, R. E. and Gibbons, N. E. (1974). Bergey's Manual of determinative bacteriology, 8th Edition. Williams and Wilkins, Baltimore. 